\title{
2. SUMMARY OF THE GEOLOGY AND GEOPHYSICS OF THE EAST PACIFIC RISE IN THE VICINITY OF THE SIQUEIROS FRACTURE ZONE
}

\author{
Bruce R. Rosendahl, Department of Geology, Duke University, Durham, North Carolina \\ and \\ Leroy M. Dorman, Scripps Institution of Oceanography, La Jolla, California
}

\begin{abstract}
The results of four expeditions to the Siqueiros area of the East Pacific Rise, including a pre-drilling site survey cruise, have been combined to yield an excellent knowledge of the areal geology and geophysics and some insight into the processes responsible for the production of sea-floor morphology, crustal structure, and chemical variations in basalts. These factors, combined with logistical and climatical considerations, were ultimately responsible for both the selection of the area for crustal drilling and many of the targets and tactics employed on Leg 54.
\end{abstract}

\section{INTRODUCTION}

Prior to Leg 54 drilling on the East Pacific Rise, the Siqueiros area had been the target of no fewer than four separate expeditions of the Scripps Institution of Oceanography: Quebrada (1969), Siqueiros (1974), Cocotow (1974), and Deepsonde II (1976) - the IPOD site survey for Leg 54. The first three expeditions were discussed in detail by Batiza et al. (1977), Dorman (1975), Orcutt et al. (1975, 1976), Rosendahl (1976), and Rosendahl et al. (1976). Deepsonde II results have so far gone unpublished, and it is one of the goals of the present paper to remedy this situation. In the interests of both brevity and relevance, we shall use a format that integrates the results of all of the above expeditions into categories that bear directly on the Leg 54 drilling results. Hence our discussion of, say, morphology and structure represents the combined results from the above and other sources, not specifically or exclusively those from Deepsonde II. We hope this will provide the reader with a comprehensive overview of what was known about the region prior to any drilling.

On another level, this report represents the geographical "package of knowledge" available to the Leg 54 scientists during their drilling operations. In this sense the paper has a direct bearing on the methods used on Leg 54 , providing both an historical perspective and a means of evaluation. To this end, we have included a section on the strategies, targets, and recommendations that were made on the basis of the information presented. Finally this paper, in combination with the following chapters, represents the regional framework into which the Leg 54 results ultimately must be interwoven.

\section{REGIONAL AND TECTONIC SETTING}

The geographic area dealt with by this paper and targeted for drilling on Leg 54 is the Siqueiros region of the equatorial eastern Pacific, or "Survey Area PT-4", in DSDP jargon. The area of interest is defined approximately by Plate 1 (in jacket at back of volume) and includes the axis and western flank of the East Pacific Rise (the Pacific plate) and the Siqueiros fracture zone region.

In terms of plate kinematics, the East Pacific Rise here represents the accreting edge of the Pacific and Cocos plates. As nearly as we can determine, the spreading has remained uniform and symmetric with respect to the rise axis for at least the past several million years, and the rate has remained essentially constant at about $60 \mathrm{~mm} / \mathrm{y}$ (half-rate) for the past $5 \mathrm{~m} . \mathrm{y}$. (Larson and Chase, 1970; Herron, 1972). On the basis of the azimuths of flow-line lineaments, it appears that the spreading direction is somewhat oblique to the rise axis, with both the Pacific and Cocos plates moving on an azimuth that is 15 to $20^{\circ}$ north of a projected orthogonal arrangement. This means that the true spreading rate here is probably a few $\mathrm{mm}$ per year higher than indicated above.

The plate configuration and geometry before about 5 m.y. ago are not well known, but there is no reason to believe that it deviates significantly from the above patterns during the interval of 5 to $10 \mathrm{~m} . \mathrm{y}$. On crust older than about 10 m.y., the Siqueiros fracture zone cannot be identified morphologically (Truchan and Larson, 1972), and Herron (1972) postulates a major reorganization of plate motions at about this time.

\section{MORPHOLOGY AND STRUCTURE}

The morphology of the Siqueiros region is essentially that of an accreting plate boundary offset by one major and at least one minor fracture zone. In addition, a number of small- to moderate-sized seamounts are superimposed on the plate fabric (here "plate fabric" refers to the general north-south arrangement of fault blocks that constitute the sea-floor relief away from the immediate vicinity of the ridge axis and which appear as 
rounded hills on shipboard echo-sounder records). The bathymetric coverage of the region is unusually good (Figure 1) and has permitted us to produce a relatively detailed and reliable contour chart (Plate 1). The remainder of this section will deal with the individual morphologic features shown in Plate 1 and their relevance to the tectonic evolution of this part of the Pacific Ocean.

\section{Rise Crest Province}

The East Pacific Rise crest in this portion of the Pacific Ocean is characterized by a 10 - to 20 -km-wide axial block (Figure 2), which stands about 200 to 400 meters above the surrounding sea floor (Anderson and Noltimier, 1973; Rosendahl, 1976). From about $8^{\circ} 15^{\prime} \mathrm{N}$ to $8^{\circ} 30^{\prime} \mathrm{N}$, this axial block is relatively flat-topped and symmetric, but further north it exhibits considerable variability. Nonetheless, the minimum depth along the top of the axial block is remarkably constant between the Siqueiros and Clipperton fracture zones and probably varies by less than about 70 meters (excluding the immediate environs of the small unnamed fracture zone at $9^{\circ} \mathrm{N}$, discussed later). Lonsdale (1977) suggests a gradual and systematic shoaling southward toward the
Siqueiros fracture zone, but the work of the present author (e.g., Rosendahl et al., 1976) does not support such a relationship. Regardless, the constancy in depth minima and the preservation of an axial block-type morphology between the Siqueiros and Clipperton fracture zones must signify a constancy of process, both from the standpoint of the hydraulic head of lavas that upwell along the top of the block and from that of the mechanisms that produce axial block topography. A corollary of this observation is the implied lack of present-day seamount production along the axis of the East Pacific Rise.

New crust formed at or near the axis of the East Pacific Rise must eventually reach the edge of the axial block and then undergo a 200- to 400-meter drop in elevation over horizontal distances of a few kilometers. Our crossings of the axial block north of the Siqueiros fracture zone strongly suggest that this elevation change occurs by faulting; however, the orientations and spacings of the faults are difficult to ascertain with seasurface instrumentation. It appears that individual fault slivers are asymmetric and tilted, with the steeper slope facing outwards. This implies step-faulting along highangle faults that dip away from the ridge axis. However,

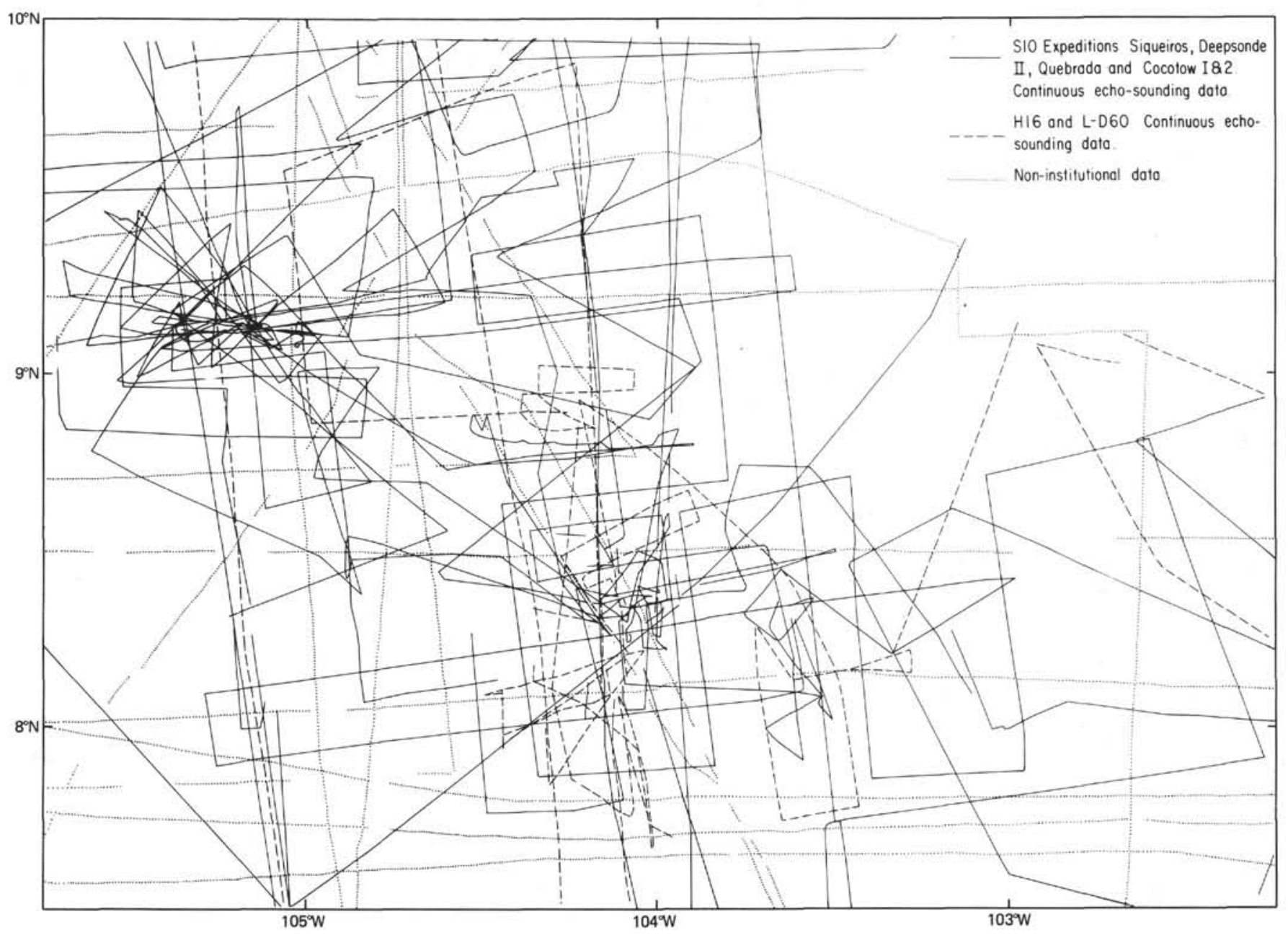

Figure 1. Bathymetric track line covering the Siqueiros region of the East Pacific Rise. Reflection profiler data were obtained along both institutional track lines. 


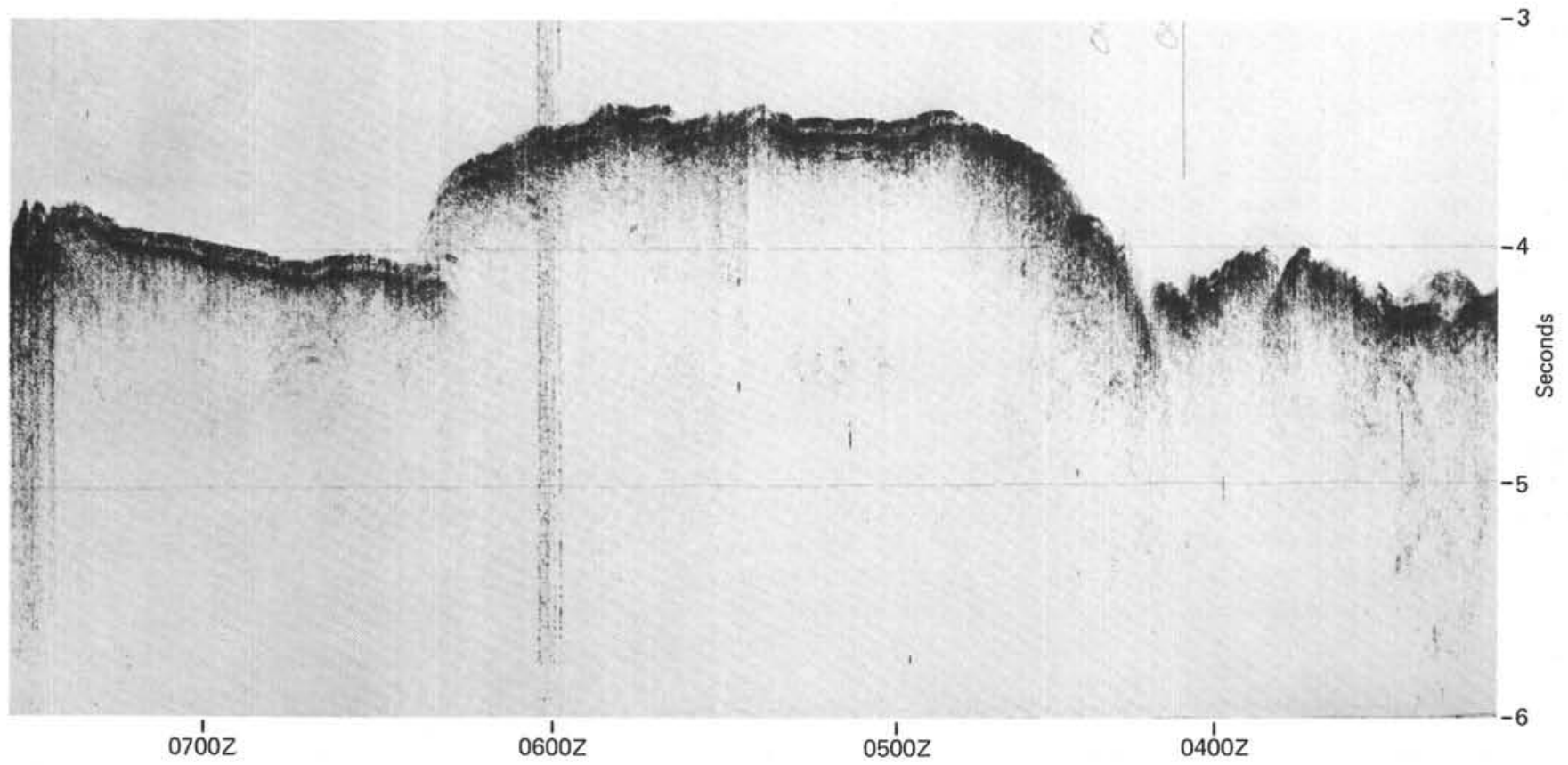

Figure 2. Reflection profiler record across the axial block of the East Pacific Rise. Profile approximately follows Deepsonde II cross-ridge refraction profile shown in Figure 4. Appearance of sediment-like reflectors on this profile is artifact of source function.

the mechanism proposed by Rea (1975) for the formation of the rise crest morphology at $10^{\circ} \mathrm{S}$ seems equally plausible to us. The reader is referred to Lonsdale and Spiess (this volume) for a near-bottom perspective of this problem.

In the region immediately south of the Siqueiros fracture zone, the East Pacific Rise is inadequately defined and on some crossings the rise crest cannot be identified with certainty. (This is indirectly illustrated in Plate 1 by the vague topographic expression of the Rise.) We believe this is a consequence of the complexity of the Siqueiros fracture zone, as we shall make clear in subsequent discussions. South of about $8^{\circ} \mathrm{N}$, the rise crest usually is marked by a bathymetric minimum, but a distinct axial block is not apparent on our crossings. It also should be noted that where the rise crest is identifiable south of the Siqueiros fracture zone, it is about 175 meters deeper than north of the Siqueiros-a dramatic finding made by Lonsdale (1977). There is some suggestion in existing data that the ridge crest depth south of the Siqueiros also is more variable than north of the fracture zone, but this is still speculative. It is most probable, however, that the Siqueiros fracture zone marks a change in both the hydraulic properties of upwelling lavas and the topography-producing mechanisms that operate along the East Pacific Rise. If this is so, then it could be predicted that this change may be recorded in the chemistry of the lavas produced on either side of the Siqueiros.

\section{Fracture Zones}

The major fracture zone in the area is, of course, the Siqueiros, located at about $8^{\circ} 15^{\prime} \mathrm{N}$. Its topographic signature is well known between about $103^{\circ} \mathrm{W}$ and $105^{\circ} 15^{\prime} \mathrm{W}$, and there can be little doubt that the lateral variability shown in Plate 1 is a valid characteristic of the feature. This variability contrasts sharply with the great northeastern Pacific fracture zones, which often preserve their cross-sectional forms over great distances (Menard, 1964). On the basis of seismological evidence, the present zone of decoupling apparently follows the northernmost trough, at least as far east as $103^{\circ} \mathrm{W}$, but the width and complexity of this fracture zone indicate that the decoupling zone has shifted with time. It is probable that this shift is a progressive one (for example, south to north) reflecting a recurring adjustment of spreading directions rather than random "decoupling chatter," perhaps intrinsic to fast spreading along very short transform faults. This would explain why the western (northern) segment of the rise crest near the transform fault intersection is relatively "clean"' and well-defined compared with its eastern counterpart, where the rise is bathymetrically vague and perhaps offset by several small fracture zones (Plate 1). Crane (1976) has proposed that isolated segments of active rise crest may be "trapped" within the Siqueiros fracture zone between what she defines as northern and southern troughs. Although speculative, such a mechanism would also explain the overall complexity of the Siqueiros, but it does not account for the vague bathymetric definition of the rise south of the Siqueiros. Regardless of how the morphologic complexity of the Siqueiros may have arisen, the conclusion can be drawn that this fracture zone is far from a simple and singular shear when considered from other than an instantaneous time perspective. Any drill holes placed within the structure's "width of influence" are likely to yield unpredicted age relationships, and perhaps atypical basalt chemistries, as well. 
A small unnamed fracture zone occurs at about $9^{\circ} \mathrm{N}$. It is observed in the bathymetry only at the rise crest (Plate 1), but can be traced as an offset in the magnetic anomalies as far west as $104^{\circ} 45^{\prime} \mathrm{W}$. In terms of offset and width, this fracture zone is comparable with Fracture Zone A in the FAMOUS area. The precise trend of this fracture zone cannot be determined from our data, but we are reasonably certain it has developed within about the past $1 \mathrm{~m} . \mathrm{y}$. This suggests that the rise axis has undergone (or is still undergoing) a recent reorientation or realignment of the spreading pattern that has historically characterized the area.

\section{Plate Fabric}

The primary plate fabric is the most pervasive aspect of the regional contour chart north of the Siqueiros fracture zone (Plate 1). The wavelength of the fabric (that is, the distance between successive bathymetric peaks) is only a few kilometers and the average depth variance from a smoothed age-depth plot would be about 50 meters, yet many individual components of the fabric can be followed in a north-south direction for tens of kilometers. This spatial continuity, combined with the high degree of parallelism of the fabric, suggests that the process of fabric production must be fairly uniform along this portion of the East Pacific Rise. We believe this process occurs as slivers of crust spall off the margins of the axial block; however, we find it surprising that the process could maintain spatial continuity over 10 or more kilometers.

As one proceeds away from the rise crest region, the plate fabric exhibits progressively less relief, linearity, and parallelism-changes that cannot be attributed to sedimentary smoothing alone. This suggests that vertical tectonic readjustments continue well after crustal generation, probably in isostatic response to a changing thermal regime. The alternative explanation - that there has been a progressive temporal change in the amount of relief originally produced - seems unlikely in view of the uniform seismic structure of the flanks of the rise, as we shall discuss in another section.

The fabric south of the Siqueiros fracture zone is notably less continuous and linear than that to the north. Admittedly, this difference is biased by the fact that our data base is much poorer in this region, but qualitatively the difference appears to be a real one. Presumably the fabric here reflects the ill-defined character of the rise crest south of the fracture zone and is perhaps related to the lack of an axial block along this segment of the East Pacific Rise.

\section{Seamounts}

There are a number of seamounts and ridges in the Siqueiros region associated with both the plate fabric and the fracture zones. The group of lineated seamounts shown in Plate 1 and Figure 3 are of particular concern, because they dissect the area targeted for drilling on Leg 54. This chain of seamounts, which was dubbed " $\mathrm{OCP}$ Ridge"' in honor of the JOIDES Ocean Crust Panel, was discovered during the Deepsonde II site survey of the PT-4 sub-area and lies within about $6 \mathrm{~km}$ of the Leg
54 prime target (e.g., Site 423). We will return to this topic in the following section. As a point of interest, normal reconnaissance profiling failed to reveal any pockets of sediments on the seamounts thick enough to provide spud-in sites for drill holes, with the exception of several of the seamounts or seamount ridges within the Siqueiros fracture zone.

The seamounts away from the fracture zones are obviously of volcanic origin, but there is considerable uncertainty regarding the location of their formation, the depths of magma genesis, and the stages of their magmatic evolution. With the discovery of a shallow magma reservoir beneath the axial block of the rise crest (see section on Crustal Structure), one might suspect that the seamounts form essentially on the rise axis from reservoir magmas which are themselves derived from deeper levels in the asthenosphere (see also Lonsdale and Spiess, 1979). As spreading progresses, the feeder systems linking the magma reservoir with the seamounts would eventually become disconnected and constructional volcanism would cease. Alternatively, it could be argued that small jumps in the spreading center locations may isolate a crustal magma reservoir and its conduits to the surface. If the reservoir continues to erupt lavas onto the sea floor for even a short period, a seamount would, of course, be formed on the flank of the rise crest. It is also possible that the seamounts are not spatially related to the subaxial reservoirs but rather are fed directly from asthenospheric sources away from the ridge axis.

The total absence of any seamounts on the rise axis at the present time and the occurrence of only one set of seamounts at equal distances on each side of the rise axis (Plate 1) argue against the first hypothesis. Dynamic or isostatic problems argue against the second hypothesis, at least with respect to large seamounts. Finally, the apparent occurrence of fundamental chemical dissimilarities between at least some of the seamount basalts and the rise crest/fabric basalts (Batiza and Johnson, this volume) argues in favor of the third hypothesis. We will return to this matter in the Petrology section of this overview.

\section{PT-4 Sub-Area}

After considerable reconnaissance surveying in Area PT-4, the Siqueiros site survey was concentrated on roughly a $1^{\circ}$ square, called the sub-area, centered at $105^{\circ} 10^{\prime} \mathrm{W}$ and $9^{\circ} 15^{\prime} \mathrm{N}$. The decision to concentrate on this sub-area was made for three reasons: (1) sediment ponds were known to exist here from previous data collections; (2) about 10 days of reconnaissance surveying had failed to locate more attractive young sites elsewhere in Area PT-4; and, (3) a prime site had to be selected by about the 15 th day of the site survey if a seismic refraction study were to be conducted.

The morphology of the sub-area essentially consists of the north-south lineated spreading fabric and the west-northwest-trending ridge of seamounts (Figure 3 ), referred to as the OCP Ridge. The existence of the 1300 -meter-high seamount located at $105^{\circ} 35^{\prime} \mathrm{W}$ and $9^{\circ} 10^{\prime} \mathrm{N}$ was suspected prior to the site survey (on the ba- 


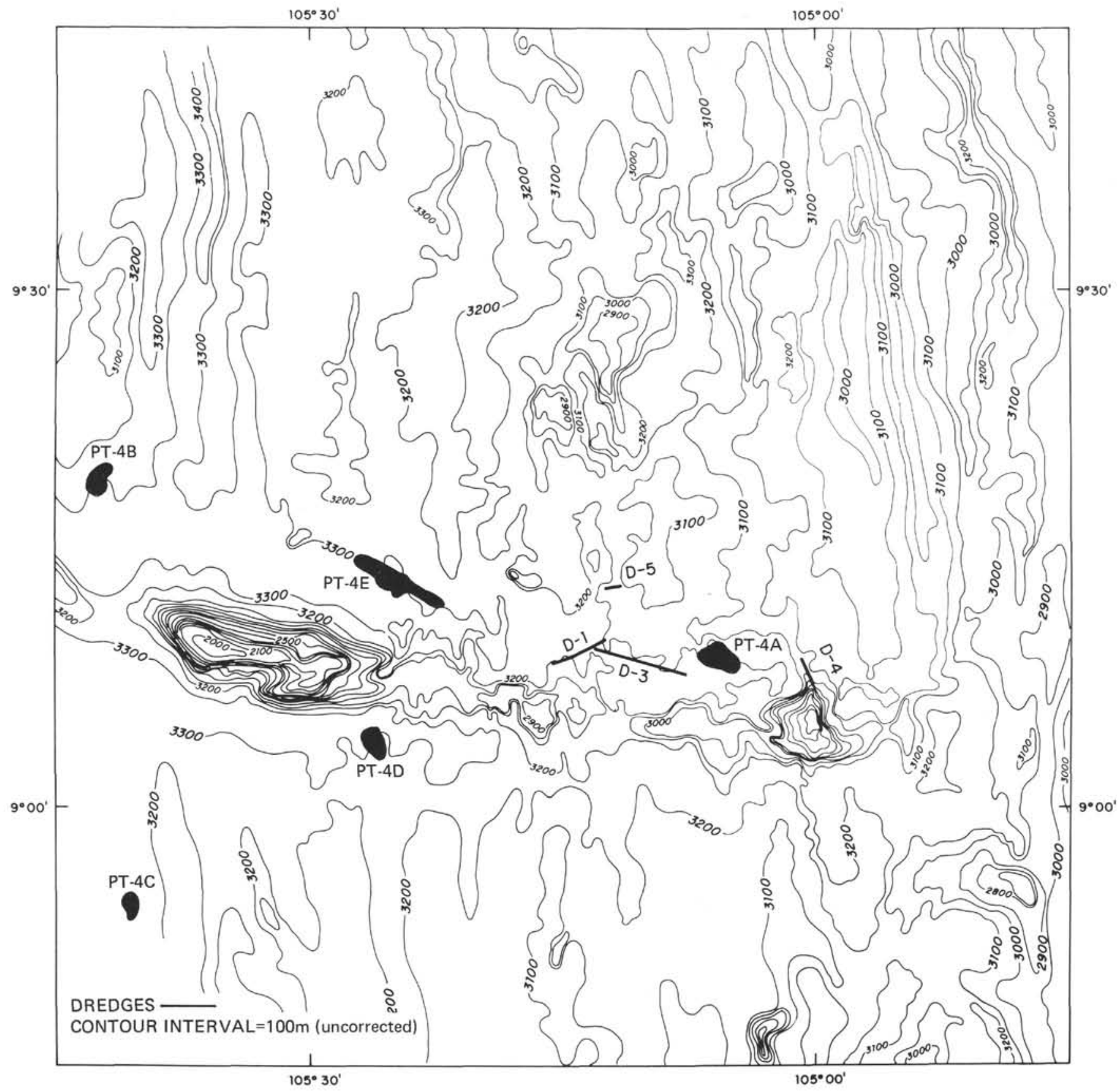

Figure 3. Bathymetric chart of the PT-4 sub-area with dredge location and possible drill targets.

sis of poorly navigated Navy soundings), and the existence of the small $(800-\mathrm{m})$ seamount at $105^{\circ} \mathrm{W}$ and $9^{\circ} 05^{\prime} \mathrm{N}$ became known toward the end of the sub-area survey. However, the fact that these features form a continuous ridge about $100 \mathrm{~km}$ long did not come to light until the bathymetry of the sub-area was contoured. Had this been known earlier, the location of the seismic experiment - and hence the Leg 54 drilling operations - would perhaps have been different. As it is, the preferred prime site for multiple re-entry (PT-4A) was located about $11 \mathrm{~km}$ from the base of the eastern seamount, but only about $6 \mathrm{~km}$ from the base of the Ridge. Moreover, the OCP Ridge is surrounded on both sides by a "moat" that is particularly well developed on its northwestern side. The preferred prime site was close to the edge of the lineated fabric, just north of the margin of this moat. The proximity of this feature to the preferred site caused concern among most of the scientists involved in Leg 54 crustal drilling and was, in part, responsible for the formulation of the original drilling strategy adopted by the Leg 54 scientific party.

The ridge connecting the eastern and western seamounts is less than 100 meters high in some localities and probably represents minor fissure eruptions along a rift zone connecting the main vents that formed the seamounts. The orthogonal alignment of the OCP Ridge 
with a short offset of the Rise Crest at about $9^{\circ} \mathrm{N}$ (Plate 1) and its parallelism to some Siqueiros fracture zone features suggest that the Ridge is associated with the small unnamed fracture zone discussed earlier. However, the Ridge does not offset the topography or magnetics and clearly is not continuous east of about $105^{\circ} \mathrm{W}$. Moreover, the feature appears to overprint (postdate) the fabric in the sub-area, suggesting that it formed away from the spreading axis. The lack of any sediments on the Ridge supports this inference. Taken in this context, the OCP Ridge probably forms a flow-line lineament with the same plate motion connotations that the Hawaiian Islands provide. The orthogonal alignment of the Ridge with the unnamed fracture zone is thus a fortuitous event without genetic implications.

Sediment distribution in the immediate vicinity of the OCP Ridge is predominantly a consequence of ponding in the surrounding moat. The sediments here are relatively uniform in thickness and show a high degree of acoustic stratification (see, for example, East Pacific Rise Site Report). They are considerably more reflective than sediments elsewhere in Survey Area PT-4. Sediment distribution away from the OCP moat is variable and unpredictable. Profiling at standard reconnaissance speeds (approximately 10 knots) revealed only a spotty distribution of sediments that was less related to topography than to the occurrence of patches of smooth seafloor. Careful profiling at slow speeds ( 2 to 4 knots) showed, in fact, that a smooth blanket of poorly stratified, moderately transparent sediment covers most of the sea-floor in the sub-area. There is a tendency towards ponding in topographic lows or against broad topographic bumps, although somewhat less than one might expect, and occasional occurrences of "puffedup" mounds of sediments, which are probably currentcontrolled.

On the basis of the acoustic character, the lithology of gravity cores, and the description of cores from the general PT-4 area, the sediment blanket away from the OCP Ridge is probably composed of a poorly sorted foraminifer-nannofossil ooze. Accumulation rates apparently average about 20 meters/m.y. Given the age of the sea floor in the vicinity of the potential drilling localities (approximately 1.5 to 2.0 m.y.), a two- to threefold increase in accumulation rate is needed to meet the spudin requirements for multiple re-entry. Only five such areas could be identified: PT-4A located at the center of the seismic array on a thickened portion of the regional sediment blanket, PT-4B, 4C, and 4D on sediment ponds at the bases of broad topographic fabric highs, and PT$4 \mathrm{E}$ on sea floor characterized by sediment mounding (Figure 3). Of these five potential drilling localities, PT$4 \mathrm{~A}$ and PT-4C were selected as the preferred and alternative targets for multiple re-entry drilling.

\section{CRUSTAL STRUCTURE}

Before the IPOD Survey of Area PT-4, the Siqueiros Expedition had yielded a knowledge of the gross crustal structure of the area (Orcutt et al., 1975; Rosendahl et al., 1976). The most publicized discovery was, of course, that the axial block is underlain by a crustal low-velocity zone which probably represents a reservoir or "resting place" for tholeiitic magmas generated at deeper levels in the asthenosphere. An equally important result of the expedition has been the realization that crustal structure is the seismological expression of a complex interplay of various factors, such as lithostratigraphy, thermal gradient, age, and degree of fracturing. The key to understanding the geologic relevance of youthful crustal structure lies in deciphering the nature of this interplay.

In the following sections we present an overview of the Siqueiros experiments (Figure 4), with particular emphasis on results that have a bearing on the drilling operations.

\section{Type Seismic Section}

Integrating the work of Rosendahl et al. (1976), Rosendahl (1976), Orcutt et al. (1975), Orcutt et al. (1976), and Garmany (personal communication), we have derived a standard model of the seismic structure of Area PT-4. In brief, the model shows a structure consisting of three compressional-wave velocity domains. The uppermost domain is a region of very rapid increase in $V p$; with depth extending from the sea floor down to about 1.5 to $2.0 \mathrm{~km}$. It overlies a domain characterized by relatively high and uniform velocities (about 6.8 to 7.0 $\mathrm{km} / \mathrm{s}$ ) that increase with depth at rates less than 0.2 $\mathrm{km} / \mathrm{s}$ per kilometer. The lowest domain is characterized by velocities greater than $7.5 \mathrm{~km} / \mathrm{s}$. These three domains represent the classical inferred basalt-gabbro-peridotite lithostratigraphy of oceanic crust, and constitute the mineralogic framework upon which effects such as thermal gradient are superimposed.

The domains are roughly coincident in depth with the standard Layer 2-Layer 3-mantle terminology; and, as a first approximation, they can be treated in an equivalent manner. However, it must be emphasized that the velocity domains are not true seismic layers separated by discontinuities, but are regions of a characteristic gradient separated by narrower zones of rapid change in gradient. It is for this reason that we do not adopt the conventional layer terminology here.

\section{Axial Low-Velocity Zone}

The interplay beteen lithostratigraphy and thermal gradient is an extreme one at the ridge axis, where the thermal gradient apparently intersects the crustal melting curve at two different depths producing a finite region of partial melt. This region manifests itself in the seismic data as a triangularly shaped low-velocity zone sandwiched between the middle and lower velocity domains (that is, between Layer 3 and the mantle).

The seismological evidence for the existence of this zone is overwhelming. First, the travel-time data show a continuous subaxial shadow zone between $7 \mathrm{~km} / \mathrm{s}$ crustal arrivals (the middle velocity domain), which abruptly terminate at moderate ranges, and $7.8 \mathrm{~km} / \mathrm{s}$ mantle arrivals. It seems that this shadow zone can be produced on the requisite geographic scale only by a velocity inversion. Secondly, the mantle arrivals are associated with anomalously large intercept times (approximately 


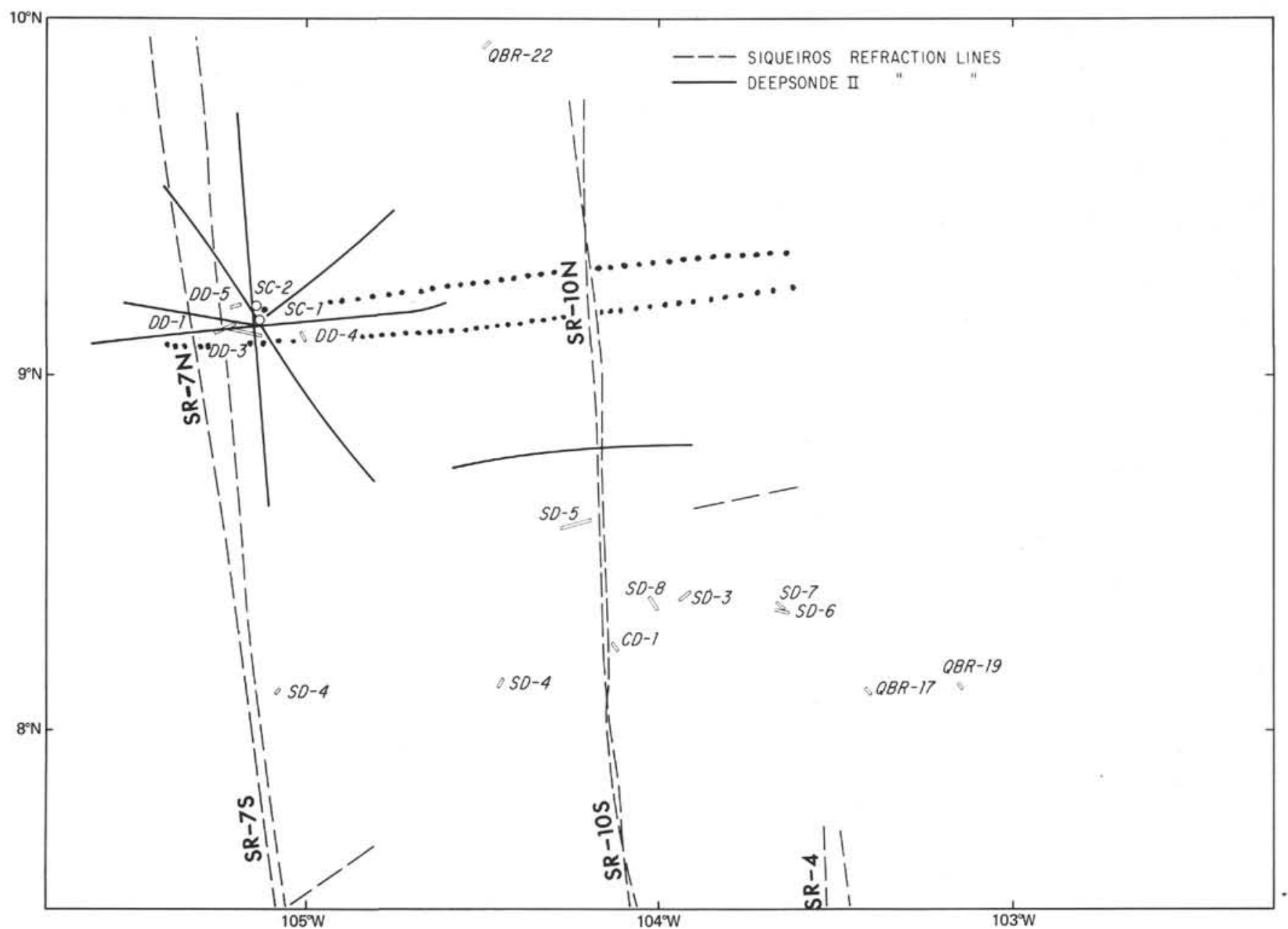

Figure 4. Seismic refraction profiles solid and dotted lines (- - - -) and rock dredges ( $\square \square \square \square$ ) in the Siqueiros area. Profiles SR-4, 10S, and 7S were shot approximately along the 1.4-, 2.4-, and 4.1-m.y. isochrons south of the Siqueiros fracture zone. Profiles $S R-10 N$ and $S R-7 N$ were shot approximately along the 0-and 2-m.y. isochron north of the Siqueiros.

$1.5 \mathrm{~s}$ after removal of the water column) which produce great apparent crustal thicknesses when a low-velocity zone is not introduced into standard layered-types of analyses. Independent evidence of this crustal velocity inversion comes from synthetic modeling of the observed wave amplitudes and patterns of energy distribution. The best models of the ridge axis record sections those that produce the best correlation between observed and synthetic data - contain a low-velocity zone of some sort, whereas the models away from the ridge do not require or even permit this inversion.

Evidence of the geometry of the zone comes from the sonobuoy refraction data, which provided coverage of the flanks of the axial block and showed a progressive thinning of the zone with distance from the ridge axis. The ocean bottom seismograph analyses (Orcutt et al., 1976) furnished an estimate of the thickness of the crust above the zone and the mean velocity within the zone, resulting in the simple seismic model of the axial intrusion zone shown in Figure 5. Evidence that the zone represents a region of partial melt is provided by the very high attenuation of seismic energy penetrating the zone and by theoretical considerations (e.g., Sleep, 1975).

\section{Genesis of the Seismic Section}

On the basis of the model shown in Figure 5 and the inference that the low-velocity zone defines a crustal magma reservoir, it is relatively easy to visualize how the type seismic section might be generated. The uppermost velocity domain probably represents a dike complex capped by basalt flows. The rapid positive velocity gradient is a consequence of the intrinsic velocity differences between the flows and dikes, smeared out by lack of a sharp contact between the two units and a decrease in pore space (that is, fracturing) with depth. The fact that a rapid thermal gradient would tend to decrease the velocity with depth suggests that temperature plays a minor role in this velocity domain. In fact, it will be shown in a later discussion that its role is not so minor as it is subtle. The loci of dike injection and the distribution of eruptive centers would be determined by the stress field of the magma reservoir, which is conducive in this region to preferential injection and eruption along the topographic axis of the crestal block. The seismic data demand that this process be restricted to the immediate locality of the ridge axis, because there 


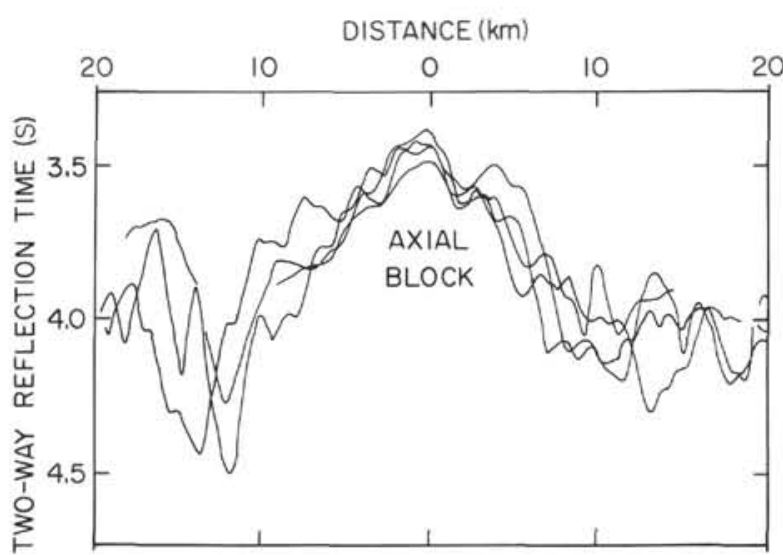

\begin{tabular}{|l|}
\hline 5.3 \\
\hline 6.9 \\
\hline 8.1 \\
\hline \\
\end{tabular}

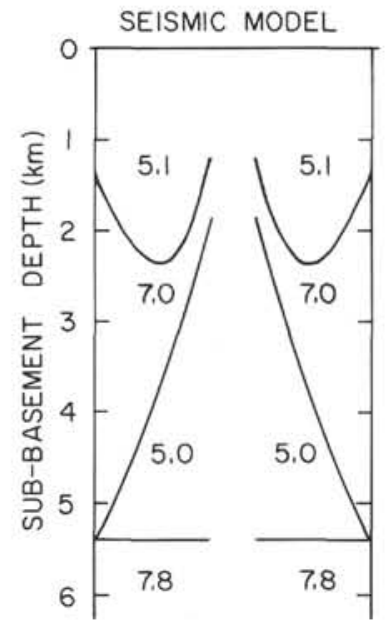

R.S.

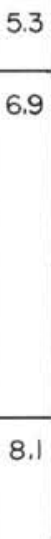

8.1

Figure 5. Seismic refraction model of the East Pacific Rise crest (after Rosendahl, 1976). Triangular-shaped, low-velocity zone is believed to represent magma reservoir.

are no systematic changes in the thickness of this domain with age (see next section). A similar restriction seems to apply to the formation of the lower seismic domain (the upper mantle), because the depth to Moho apparently remains relatively constant beneath the entire axial block. This suggests that the upper mantle is generated essentially at the ridge axis. It appears certain that the $7.8 \mathrm{~km} / \mathrm{s}$ Moho that floors the reservoir represents an ultramafic cumulate of dense early-formed mineral phases with little or no melt present. The seismic velocity of the mantle is basically a function of original mineralogy at elevated but sub-melt temperatures.

In contrast to the upper and lower seismic domains, the genesis of the middle domain (that is, Layer 3 ) is not entirely restricted to the immediate vicinity of the ridge axis. The thickness of this domain increases with age from a few hundred meters near the ridge axis to about $4 \mathrm{~km}$ at the edge of the axial block - a rate of thickening of about 500 meters $/ \mathrm{km}$ of distance - at the expense of the low-velocity zone (Figure 5). Hence, progressively deeper parts of the domain evolve from the partial melt zone (that is, they pass through the solidus) at progressively greater distances from the ridge axis, al- though the accretion is completed within the boundaries of the axial block. The top few hundred meters of the domain still must be formed essentially at the ridge axis, because high compressional-wave velocities are observed everywhere above the low-velocity zone. We believe that this early-formed material could be a plagioclase-rich gabbro which caps the summit of the partial melt zone and produces a thin, high-velocity lid. The base of this domain probably consists of high-density precipitates (olivine + pyroxene + opaque minerals) plus plagioclase formed from trapped pockets of intergranular melt. The velocity in this material would be slightly higher than that in the plagioclase-rich gabbroic lid, accounting for the slight positive velocity gradient in this domain and the apparent transition zone between it and the mantle. The material sandwiched between the gabbroic lid and the basal precipitates would be a heterogeneous mixture of gabbroic rock types with local pockets of late-stage differentiates. The maximum velocity in these rocks, although variable, probably does not exceed that in the gabbroic lid, and in some instances would be less.

\section{Age Variations in the Seismic Section}

The major change in gross crustal structure with age is the thickening of the middle velocity domain (Layer 3 ) at the expense of the partial melt zone (Figure 5). This is a primary change involving the genesis of the lithostratigraphy of the bulk of the crust. No significant thickness changes were observed in the other velocity domains elsewhere in the study region. Moreover, the thickness of the middle domain appears to attain constancy once it spreads beyond the confines of the axial block.

In spite of the lack of thickness variations, there do appear to be systematic, albeit subtle, changes in seismic velocities with age. Both thick-layered and gradient model analyses suggest a slight decrease in mantle velocity (parallel to the ridge axis) in the first several million years after formation. The variation is about $0.3 \mathrm{~km} / \mathrm{s}$, decreasing from a high of about 7.7 to $7.8 \mathrm{~km} / \mathrm{s}$ at the ridge axis to a low of about 7.4 to $7.5 \mathrm{~km} / \mathrm{s}$ between the 2.0- and 2.4-m.y. isochrons (Figure 4). Between the 2.0and 4.1-m.y. isochrons, the gradient analyses show an increase in mantle velocity from about 7.4 to $7.5 \mathrm{~km} / \mathrm{s}$, to about $8.0 \mathrm{~km} / \mathrm{s}$. This $0.5 \mathrm{~km} / \mathrm{s}$ increase is an actual observation (that is, greater than the uncertainty limits) and, if generally valid, reflects the lowering of the thermal gradient as the mantle gradually cools. The initial $0.3 \mathrm{~km} / \mathrm{s}$ decrease in mantle velocity is at the resolution limit and hence may or may not be a real phenomenon. If real, the decrease would imply an initial reversal in mantle cooling with age. We have no explanation for this possibly anomalous behavior in the first several million years after genesis.

No significant velocity changes are observed in the middle velocity domain, except perhaps for a slight decrease in the gradient value with age. This change is easily explained by a decrease in the temperature gradient, which should also produce an analogous decrease in the 
velocity gradient with age in the upper domain and a corresponding increase in its mean velocity. The latter point appears to be supported by the thick-layered analyses, which suggest a slight increase in the velocity of the "Layer 2" refractor and in the mean velocity of this domain between the ridge and the 2.4-m.y. isochron (Figure 4). The gradient analyses, on the other hand, suggest that the rate of change in velocity with depth in this domain increases from about $0.75 \mathrm{~km} / \mathrm{s} / \mathrm{km}$ near the ridge axis to about $1.75 \mathrm{~km} / \mathrm{s} / \mathrm{km}$ at ages of 2.4 and $4.1 \mathrm{~m}$.y. There is an apparent contradiction here between the two analytical techniques, which is difficult to resolve at this time. The problem is that the thick-layered analyses, although normally much cruder than the gradient analyses, are based upon averages of many profiles along each of the isochrons, whereas the more sophisticated gradient analyses are based upon single isochronal profiles with relatively few shots in the range-where the upper domain refractions appear as first arrivals. If the thick-layered analyses are correct, then the velocity variations in the upper domain are easily attributable to simple cooling. However, if the gradient values are proven correct then it will be necessary to postulate a radical decrease in the velocity of the near surface rocks in the first several million years after crustal genesis. The only plausible mechanism would be fracturing as the crust spread away from the ridge axis, perhaps associated with the faulting that must occur at the margins of the axial block.

\section{Spatial Variations in the Seismic Section}

One of the most surprising results of the Siqueiros experiments in Area PT- 4 was the uniformity of the crustal structure along the off-ridge isochron shooting lines (that is, the 1.4- and 2.4-m.y. profiles shown in Figure 4). There are no multiple OBS lines along any isochron to provide a check on subtle variations in velocity gradient, but thick-layered analyses of the multiple sonobuoy profiles clearly show that first-order isochronal changes in velocities and thicknesses are absent. Indeed, if the data along each isochron are plotted as though they originated at a single receiver, it is found that the standard deviation of the arrival times from those produced by the mean structure is equal to or less than the experimental error. We interpret this lack of isochronal variation to signify that the process of crustal generation at or near to the ridge axis is uniform along this part of the East Pacific Rise. Since the process has not varied significantly between isochronal lines either (see previous section), there must be a temporal and spatial stability for crustal generation on the scale of at least a few million years and several hundred kilometers.

\section{PETROLOGY}

\section{Regional Summary}

Most of the rock samples from the Siqueiros region (Figure 4) range from highly LIL-depleted mid-ocean ridge basalt to progressively more fractionated tholeiitic basalts (Batiza et al., 1977). Taken as a group, the tholeiites contain 6 to 10 per cent $\mathrm{MgO}$ and show continuous enrichment in $\mathrm{Fe}, \mathrm{Ti}, \mathrm{Mn}, \mathrm{Na}, \mathrm{K}$, and $\mathrm{P}$ on $\mathrm{MgO}$-variation diagrams (Figure 6), accompanied by progressive depletion in $\mathrm{Ca}, \mathrm{Al}, \mathrm{Ni}$, and $\mathrm{Cr}$. Because these trends can be explained by the subtraction (crystallization) at shallow depth of large amounts of analyzed olivine plus plagioclase plus clinopyroxene from the most Mg-rich specimens, it is likely that these rocks represent various stages of fractionation within the crustal magma reservoir that is believed to underlie the rise crest (Batiza et al., 1977). The wide range in degree of fractionation in these rocks and the abundance of relatively fractionated specimens is characteristic of lavas erupted at axial block-type ridge systems (e.g., East Pacific Rise) and contrasts with lavas erupted at axial valley-type ridges (Rosendahl, 1976). We believe this difference could reflect variations in the size of the magma reservoirs beneath both types of ridges.

Two groups of rocks dredged in the Siqueiros region do not fall into the tholeiite fractionation pattern described above. One group, from dredge SD-7 (Figure 4), is an assemblage of spectacularly fresh picritic "basalts" containing olivine phenocrysts $\left(\mathrm{Mg}_{90}\right)$ as large as $5 \mathrm{~mm}$ and unzoned plagioclase microlites in a matrix of glass. Pyroxene phenocrysts do not occur in these rocks, which are among the most "primitive" ever recovered from the sea floor. They are the subject of a separate chapter by Schrader et al. in this volume. The other group, recovered from dredge SD-8 at the intersection of the East Pacific Rise and the Siqueiros fracture zone, are alkali basalts with a chemistry not entirely like that of any other alkali basalts. This unique chemistry suggests rather extensive partial melting ( 20 to $25 \%$ ) of a shallow mantle source $(P<10 \mathrm{kbar})$, followed by enrichment in LIL elements by wall/rock interaction and/or zone refining without significant crystal fractionation - an evolutionary scheme that may reflect the peculiarities of secondary volcanic processes resulting when earlier-formed transform fault-bounded lithosphere re-enters the thermal regime of the western segment of the East Pacific Rise (Batiza et al., 1977).

\section{PT-4 Sub-Area}

Based upon partial chemical analyses, the rocks from dredges D-1 and D-5 in the PT-4 Sub-area (Figure 3) are LIL-depleted mid-ocean ridge tholeiites with $\mathrm{MgO}$-variation trends similar to those found by Batiza et al. (1977). Apparently these rocks represent further examples of the ridge-crest tholeiites dredged elsewhere in the area. Some of the rocks from dredges D-3 and D-4 also are normal, LIL-depleted tholeiites, but in addition these dredges contain basalts that show a tendency towards enrichment in $\mathrm{P}_{2} \mathrm{O}_{5}$ with respect to $\mathrm{TiO}_{2}$ and depletion in $\mathrm{CaO}$ with respect to $\mathrm{Al}_{2} \mathrm{O}_{3}$ (Figures 7 and 8 ). The basalts are also enriched in LIL- and light-rareearth elements compared with the more typical ridgecrest tholeiites, and have a higher ${ }^{87} \mathrm{~S} / 86 \mathrm{~S}$ ratio (Batiza and Johnson, this volume). This amounts to a trend toward transitional basalts or even the alkalic basalts found in dredge SD-8.

The occurrence of more alkalic basalts in dredge D-4 is not surprising since it partially sampled the base of the 

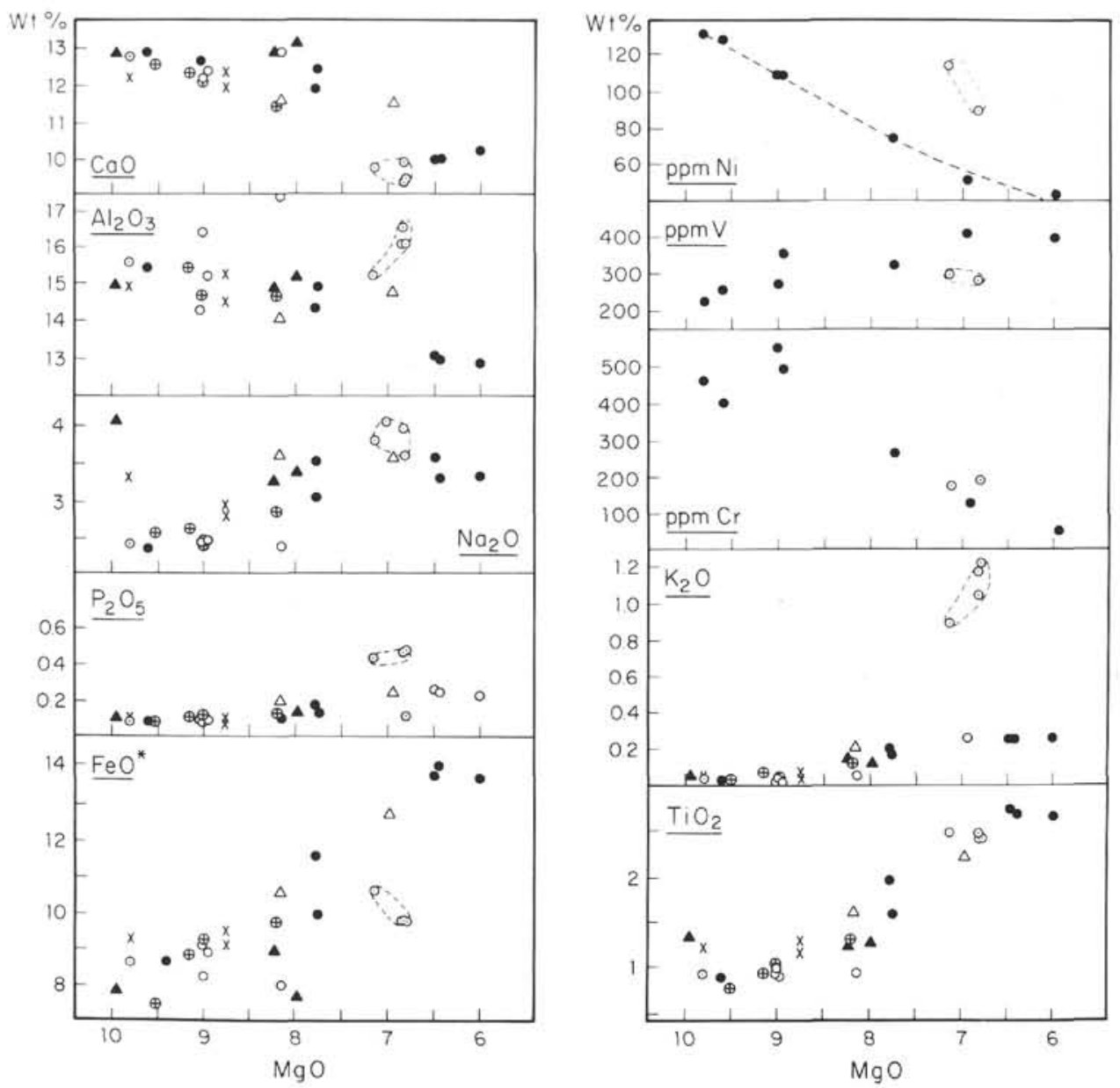

Figure 6. $\mathrm{MgO}$ variation diagrams for Siqueiros basalt (after Batiza et al., 1977).

For all oxide diagrams, open circles refer to dredge $S D-3$, crosses $S D-4$, open triangles $S D-5$, solid circles $S D-6$, circled dots $S D-8$, solid triangles $C D-1$, and circled plus signs $Q B R$. See Figure 4 for dredge locations. For $\mathrm{Ni}, \mathrm{Cr}$, and V, solid circles represent tholeiites, circled dots alkali basalts. Dashed lines enclose alkali basalts.

seamount at the eastern end of the OCP Ridge (Figure 3 ), but the occurrence of transitional to alkalic tendencies in some rocks from dredge D-3, which sampled the northern tip of the moat surrounding the OCP Ridge, was somewhat unexpected. Apparently, the moat is floored, in part, by the OCP Ridge lavas originating from fissures off the main trend of the Ridge. Because drill target PT-4A is located on the north-south lineated topographic fabric, which dredges D-1 and D-5 suggest is chemically normal, it is likely that it has not been influenced by the OCP Ridge (or moat) volcanism. Still, target PT-4A is only 2 to $3 \mathrm{~km}$ from its nearest approach to dredge D-3, and the possibility of contamination is indeed a real one. The drilling strategy outlined in Figure 9 and Chapter 1 of this volume was designed to test this possibility prior to establishing a multiple reentry hole at Target PT-4A.

\section{MAGNETICS AND GRAVITY}

Figure 10 shows a plot of magnetic anomalies along some of the longer east-west tracks in the PT-4 area. Because of the proximity of the study region to the mag- netic Equator, the spreading anomalies are of relatively low amplitude. Nonetheless, the Jaramillo (Anomaly 1) and Gilsa (Anomaly 2) events can be identified in the part of the Siqueiros area that lies north of the Siqueiros fracture zone and west of the rise crest. The latter event is particularly well defined and there can be little doubt of its identification in Figure 10, whereas the central anomaly is poorly developed in the study region. In the absence of bathymetry, the central anomaly would not be identifiable to the untrained eye. The small unnamed fracture zone that offsets the rise crest at $9^{\circ} \mathrm{N}$ may disrupt the continuity of Anomaly 1 but not that of either the positive anomaly immediately to the west of it or Anomaly 2. Apparently this fracture zone developed less than a million years ago in spite of the fact that the OCP Ridge, which rests on crust greater than a million years old, may line up orthogonally with it. It also should be noted that most of the seamounts and larger-scale fabric topography have little expression in the magnetics.

The major result of the gravity studies in Area PT-4 has been the demonstration by Dorman (1975) that the depth of isostatic compensation beneath the axial block 


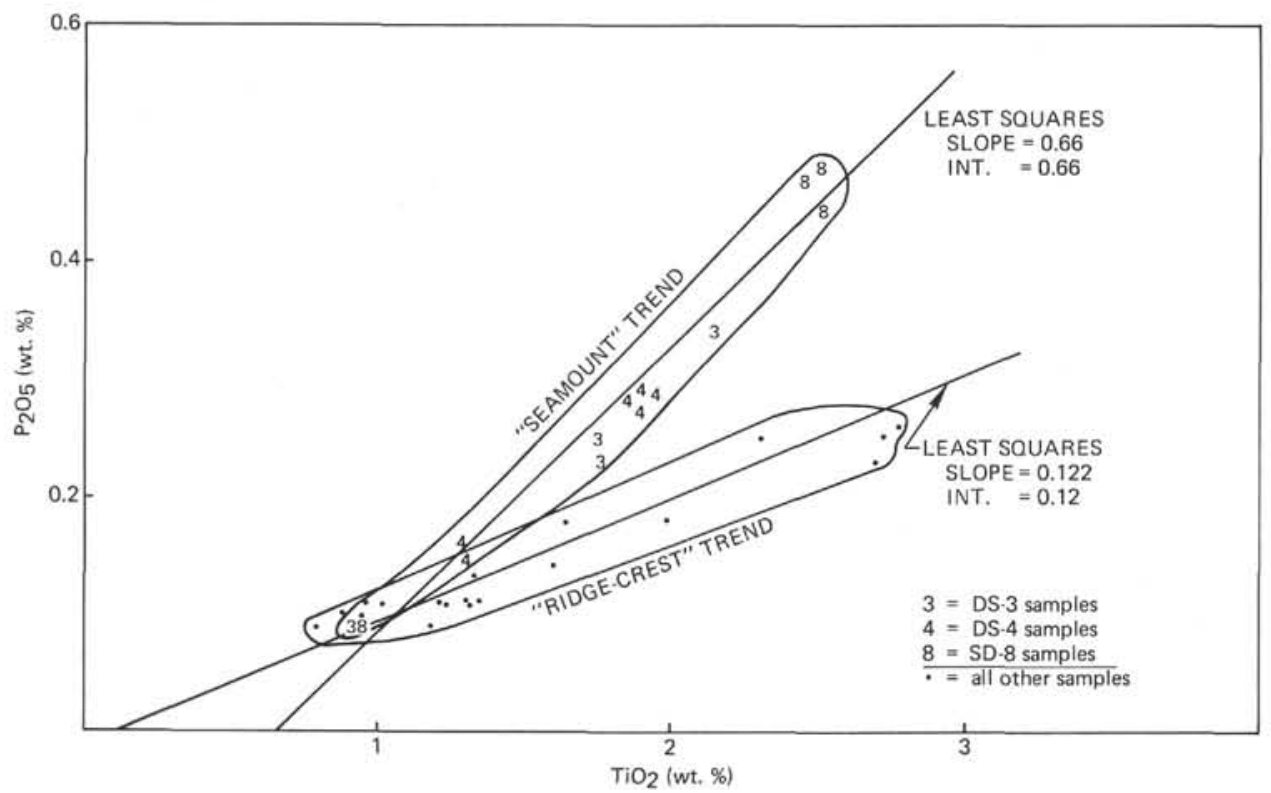

Figure 7. Plot of $\mathrm{P}_{2} \mathrm{O}_{5}$ versus $\mathrm{TiO}_{2}$ for all Siqueiros dredge hauls including PT-4 sub-area dredges. Siqueiros data from Batiza et al. (1977); sub-area data from Johnson (unpublished).

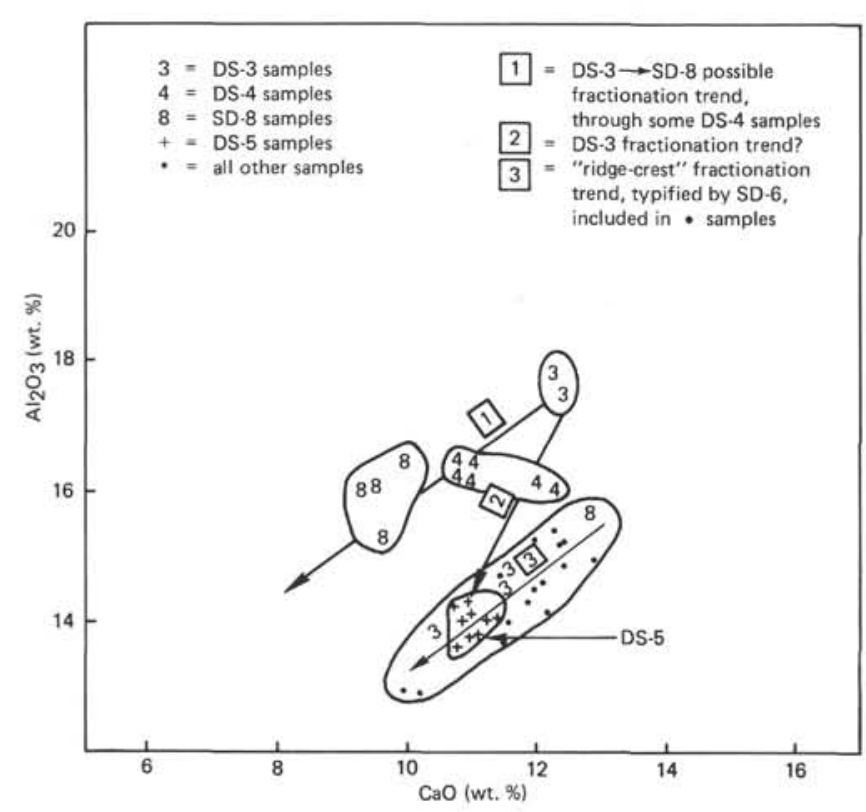

Figure 8. Plot of $\mathrm{CaO}$ versus $\mathrm{Al}_{2} \mathrm{O}_{3}$ for all Siqueiros dredge hauls PT-4 sub-area dredges. Siqueiros data from Batiza et al. (1977); sub-area data from Johnson (unpublished).

region of the East Pacific Rise is about an order of magnitude less than that found in the continental United States, or about $10 \mathrm{~km}$ for the axial block. This value is further evidence that the rise crest morphology is an isostatic response to the shallow magma reservoir thought to underlie the axial block (Rosendahl, 1976).

\section{DRILLING RECOMMENDATIONS BASED ON THE SITE SURVEY AND PRIOR CRUISES}

\section{General}

On the basis of the results presented, we recommended that the Siqueiros area of the East Pacific Rise (i.e., Survey Area PT-4) be chosen as the type-drilling area for fast-spreading, young oceanic crust. Because this recommendation was accepted and ultimately gave rise to Leg 54, it is appropriate to list here the reasons for the recommendation:

1) The area is very well surveyed and bathymetrically represents the best known segment of an accreting-plate margin in the fast-spreading Eastern Pacific.

2) The seismic structure of the crust is at least better known, and probably better understood, than the structure of any comparable area of accreting-plate boundary.

3) The pre-drilling petrologic control in the area exceeded that available to most other ocean crust drilling legs and can be used to place the drill-hole data in their proper perspective.

4) The rise crest in the area is characterized by an axial block $-a$ feature that typifies the East Pacific Rise spreading axis.

5) A realistic opportunity exists for relating basalt stratigraphy and chemistry with the physicochemical processes that may be occurring in the axial magma reservoir; the latter presumably represents the final "staging area" of the basalts prior to their eruption or injection. The inadequate understanding of the structure of other ridge crests automatically eliminates a true process-response type of study elsewhere. 


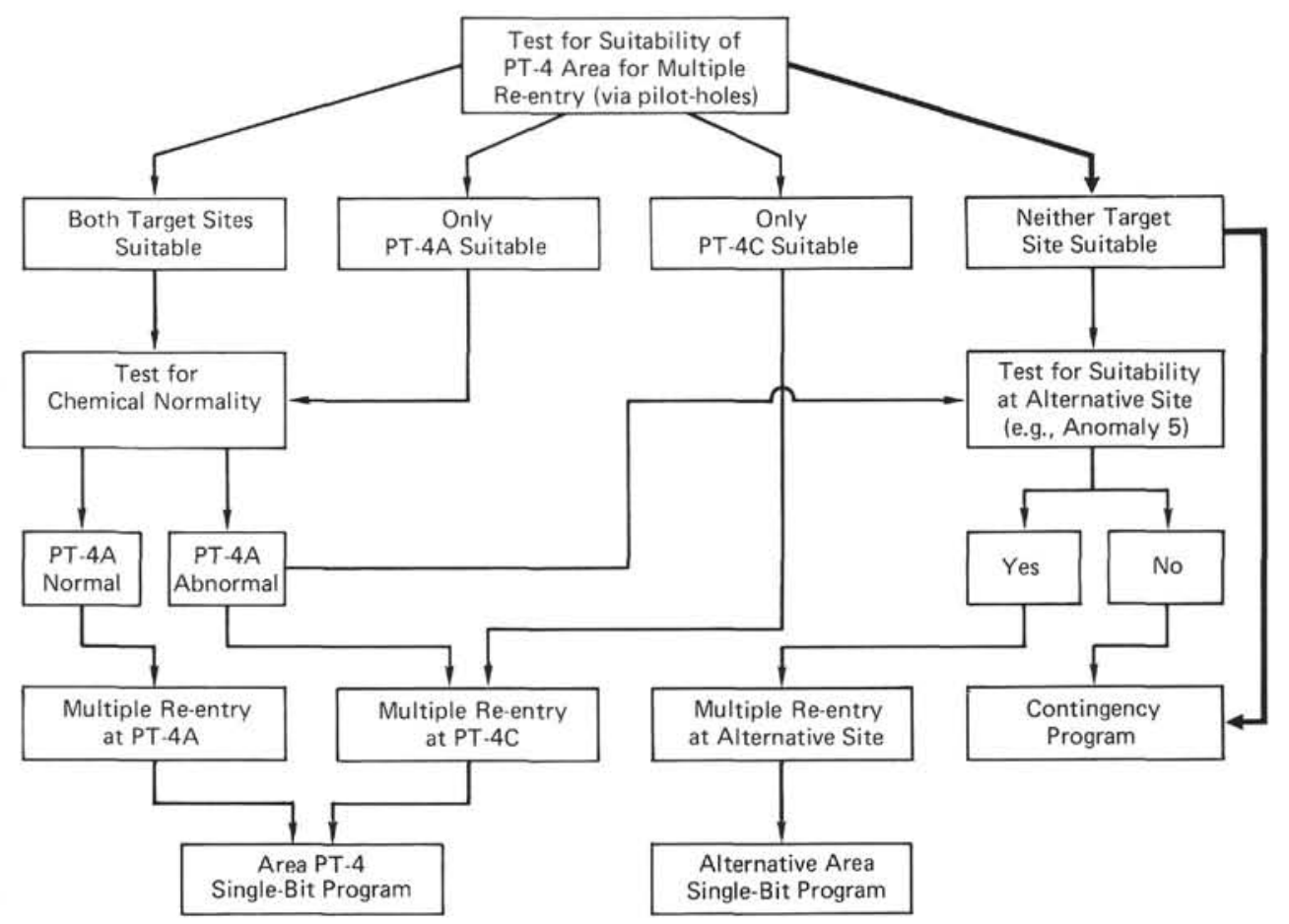

Figure 9. Flow diagram of recommended drilling strategy for Leg 54.

6) The area is logistically and climatically amenable to multiple re-entry drilling and follow-up studies, yet is located well beyond any territorial waters.

\section{Targets, Tactics and Specific Recommendations}

Although the advantages mentioned in choosing Area PT-4 as the type-drilling area for fast-spreading young crust were relatively obvious, the selection of actual target localities for multiple re-entry was complex. The main reason was that the minimum sediment requirements for spud-in (approximately $80 \mathrm{~m}$ ) dictate the locations of potential target areas, and among the limited number of resulting targets no single one is ideal. In order to choose between the five potential targets that meet the sediment requirements (Figure 3), the following criteria were used, in order of importance:

1) The "normality" of a given target in terms of its sea-floor morphology, igneous petrology and chemistry, and geophysical signature.

2) The likelihood of correlating remote seismic measurements at a given target with its downhole lithology.

3) The youthfulness of a given target and its proximity to the center of a normal or reversed magnetic block.

Site PT-4A was the superior location from the standpoint of seismic correlation, youthfulness, and magnetic criteria, but it was sufficiently close to the OCP Ridge to question whether it was structurally and chemically typical. Indeed, as indicated in the petrologic discussion, some rocks from dredge D-3 (located about 2 to 3 $\mathrm{km}$ from PT-4A) show chemical affinities with the transitional basalts found in dredge D-4, which was located on the northern edge of the OCP Ridge. Even though PT-4A appeared to be located on the north-south lineated spreading fabric and dredge D-3 along the margin of the "moat" surrounding the OCP Ridge, the uncertainty regarding its petrologic typicality required that an alternate multiple re-entry site be chosen. Site PT $-4 \mathrm{C}$ was that locality. It must be realized that the alternative site, although probably normal from a petrochemical standpoint, is located outside the limits where seismic control is significant. Hence, if PT-4C were chosen, Leg 54 would sacrifice the opportunity of seismological correlation for the sake of presumed petrochemical normality. This would have been a painfully high price to pay and one upon which not all interested parties were in full agreement. For this reason and because the mechanical suitability of a given re-entry target could not be predicted prior to actual drilling, a recommendation was also made that single-bit pilot holes be drilled at both targets PT-4A and PT-4C. The four possible results of pilot-hole drilling, outlined in Figure 9, would determine what course of action should be followed by the shipboard party.

In addition to the pilot holes at PT-4A and $4 \mathrm{C}$, we recommended drilling one or more single-bit holes at unspecified localities in the moat between the OCP Ridge and PT-4A, and at PT-4D. These holes were to be drilled on a "time-available basis" with the objective of further chemical characterization of the OCP Ridge lavas, both in time and space.

\section{Alternative and Contingency Plan}

In the event that the PT-4 sub-area proved unsuitable for drilling, we recommended that an alternative site be chosen in the vicinity of magnetic anomaly 5 . The program should include multiple re-entry and closely spaced, 


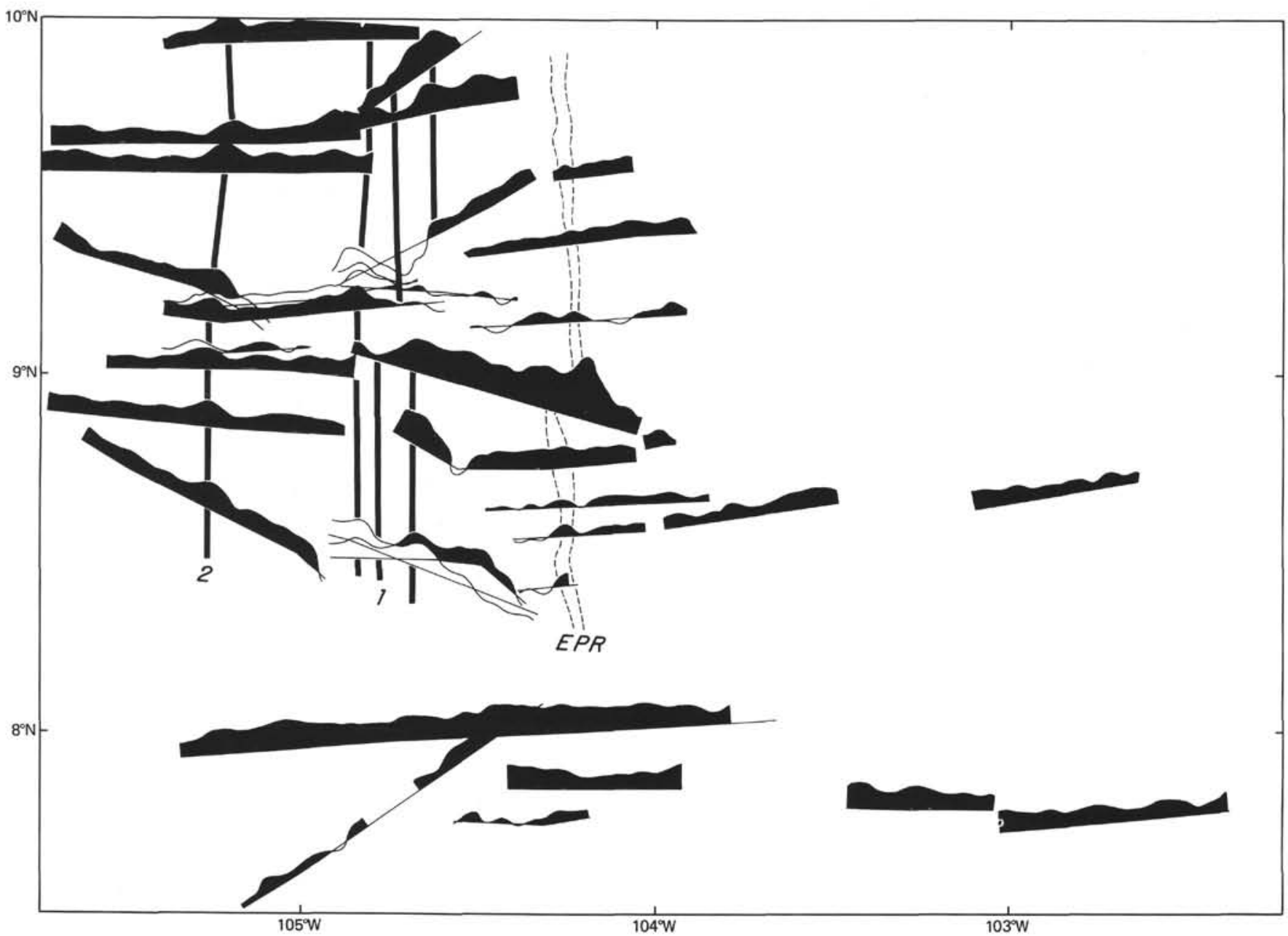

Figure 10. Magnetic anomalies plotted along selected east-west profiles in the Siqueiros area. Margin of East Pacific Rise axial block shown as dotted lines. Numbers refer to probable anomaly numbers.

single-bit holes. If multiple re-entry again proved not feasible, we recommended that the Pacific flow-line transect of single-bit holes be continued westward for the duration of Leg 54. This constitutes the contingency program identified in Figure 9.

As it turned out, the final drilling program of Leg 54 differed considerably from the plans presented here. The drilling program, and the reasons for it, are outlined in the introduction and site chapters of this volume.

\section{REFERENCES}

Anderson, R., and Noltimier, H. C., 1973. A model for the horst and graben structure of mid-oceanic ridge crests based upon spreading velocity and basalt delivery to the oceanic crust. Geophys, J. Roy. Astron. Soc., v. 34, p. 137-147.

Batiza, R., Rosendahl, B. R., and Fisher, R. L., 1977. Evolution of oceanic crust: 3 . Petrology and chemistry of basalts from the East Pacific Rise and Siqueiros transform fault. J. Geophys. Res., v. 82, p. 265-276.

Crane, K., 1976. The intersection of the Siqueiros Transform Fault and the East Pacific Rise. Mar. Geol., v. 21, p. 25-46.
Dorman, L. M., 1975. The isostatic compensation of the topography at the crest of the East Pacific Rise. EOS Trans. Amer. Geophys. Union, v. 56, p. 1964, Abstract T49.

Herron, E. M., 1972. Sea-floor spreading and the Cenozoic history of the east-central Pacific. Geol. Soc. Am. Bull., v. 83 , p. 1671-1692.

Larson, R. L., and Chase, C. G., 1970. Relative velocities of plate tectonic history of the mouth of the Gulf of California. Ibid., v. 83, p. 3345-3360.

Larson, R. L.. and Chase, C. G., 1970. Relative velocities of the Pacific, North America, and Cocos Plates in the Middle America region. Earth Plant. Sci. Lett., v. 7, p. 425-428.

Lonsdale, P., 1977. Regional shape and tectonics of the equatorial East Pacific Rise. Mar. Geophys. Res., v. 3, p. 295-315.

Lonsdale, P., and F. N. Spiess, 1979. A pair of young cratered volcanoes on the East Pacific Rise, J. Geol., v. 87, p. 157-173.

Menard, H. W., 1964. Marine Geology of the Pacific: New York (McGraw-Hill).

Orcutt, J. A., Kennet, B. L. N., Dorman, L. M., and Prothero, W. A., 1975. Evidence for a low-velocity zone underlying a fast-spreading rise crest. Nature, v. 256, p. 475.

1976. Structure of the East Pacific Rise from an ocean bottom seismometer array. Geophys. J. Roy. Astron. Soc., v. 45, p. 305-320. 
Rea, D. V., 1975. Model for the formation of topographic features of the East Pacific Rise crest. Geol., v. 3, p. 77-80.

Rosendahl, B. R., 1976. Evolution of oceanic crust, 2, Constraints, implications, and inferences. J. Geophys. Res., v. 81, p. 5305-5314.

Rosendahl, B. R., Raitt, R. W., Dorman, L. M., Bibee, L. O., Hussong, D. M., and Sutton, G. H., 1976. Evolution of oceanic crust, I, A physical model of the East Pacific Rise crest derived from seismic refraction data. J. Geophys. Res., v. 81, p. 5294-5305.

Sleep, N. H., 1975. Formation of ocean crust: Some thermal constraints. Ibid., v. 80 , p. 4037-4042.

Truchan, M., and Larson, R.L., 1972. Tectonic lineaments on the Cocos Plate. Earth Planet. Sci. Lett., v. 17, p. 426-432. 